\title{
Circular ENH878
}

\section{E X T E N S I O N}

Institute of $\mathbf{F}_{\text {ood and }} \mathbf{A}$ gricultural $\mathbf{S}_{\text {ciences }}$

\section{Croton Production and Use 1}

\author{
Robert H. Stamps and Lance S. Osborne ${ }^{2}$
}

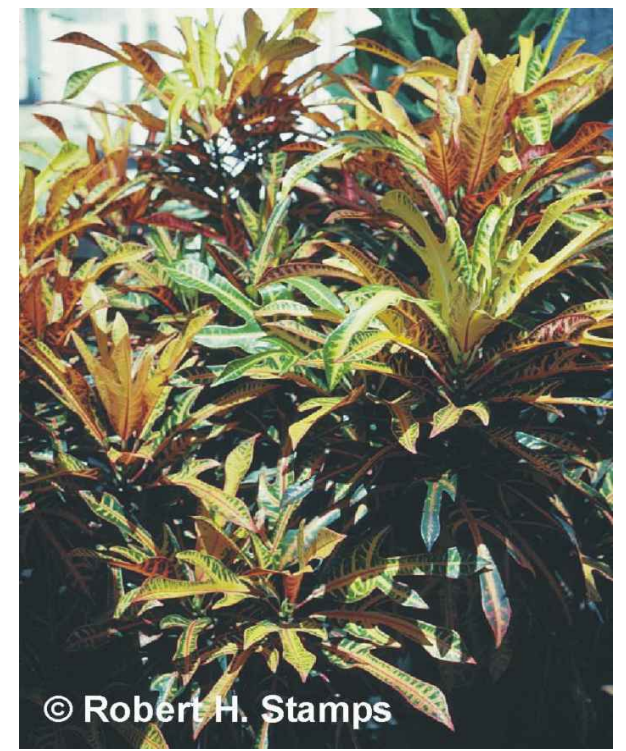

Figure 1. Crotons are useful for adding color to floral arrangements, landscapes and interiorscapes.

FAMILY: Euphorbiaceae

GENUS: Codiaeum

CULTIVARS: 'Banana', 'Gold Dust', 'Mammy', 'Norma', 'Petra', 'Sunny Star' and many others.

Crotons have been popular in tropical gardens for centuries. Crotons grow into shrubs and small trees in their native habitats of India, Malaysia, and some of the South Pacific islands. Few other plants can surpass them in both foliage color and leaf shape variation. Leaf colors range from reds, oranges and yellows to green with all combinations of variegated colors. Leaf shapes vary from broad and elliptical to narrow and almost linear. Leaf blades range from flat to cork-screw-shaped. Since some cultivars are tolerant of interior environments, crotons have also become very popular as interior potted foliage plants. One additional point, often overlooked, is that foliage of crotons is excellent material for use in floral SPECIFIC EPITHET: variegatum arrangements. Both individual leaves and entire branches can be used in floral designs.

1. This document is Circular ENH878, one of a series of the Environmental Horticulture Department, Florida Cooperative Extension Service, Institute of Food and Agricultural Sciences, University of Florida. Original publication date March 2003. Reviewed December 2002. Visit the EDIS Web Site at http://edis.ifas.ufl.edu.

2. Robert H. Stamps, Professor of Environmental Horticulture and Extension Cut Foliage Specialist, and Lance S. Osborne, Professor of Entomology, Mid-Florida Research and Education Center, Apopka, FL.

The use of trade names in this publication is solely for the purpose of providing specific information. UF/IFAS does not guarantee or warranty the products named, and references to them in this publication does not signify our approval to the exclusion of other products of suitable composition. All chemicals should be used in accordance with directions on the manufacturer's label. Use pesticides safely. Read and follow directions on the label.

The Institute of Food and Agricultural Sciences is an equal opportunity/affirmative action employer authorized to provide research, educational information and other services only to individuals and institutions that function without regard to race, color, sex, age, handicap, or national origin. For information on obtaining other extension publications, contact your county Cooperative Extension Service office. Florida Cooperative Extension Service/Institute of Food and Agricultural Sciences/University of Florida/Christine Taylor Waddill, Dean. 


\section{Floral Design, Landscape and Interiorscape Use}

\section{Floral Design Use}

The colorful foliage of crotons is used in several ways in floral arrangements. Narrow croton leaves are used as line (linear) materials, brilliantly-colored leaves can add a mass of color to arrangements, and large croton leaves can be used as form material. Croton foliage provides numerous colors (red, yellow, green, black, pink and orange) and is used in corsages, flower arrangements and wedding bouquets. Care must be exercised to avoid staining by the sap of freshly harvested leaves. The foliage of crotons is available year round and adds an exotic touch to floral designs.

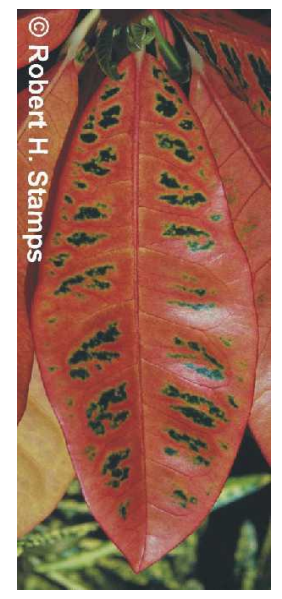

Figure 2. Croton cultivars come in many leaf shapes and colors. Pictured here is the cultivar 'Petra'.

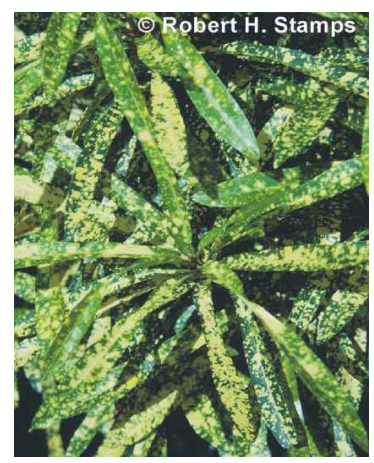

Figure 3. Croton cultivar 'Gold Star'.

\section{Landscape Use}

Crotons are shrubs that can grow up to six feet or more in height and width. In south Florida and in warmer parts of central Florida, they are evergreen. They are commonly used as accent and foundation

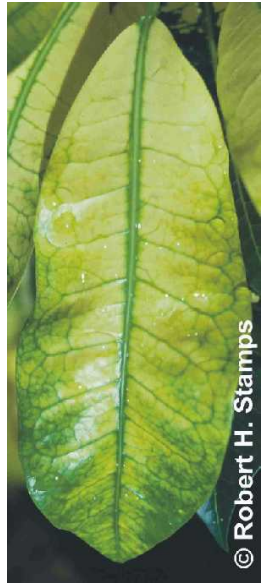

Figure 4. Croton cultivar 'Yellow Icing'.

plants and can be used effectively in mass plantings and in planters. Crotons can be grown in full sun or partial shade and, once established, are drought tolerant.

\section{Interiorscape Use}

Acclimatized croton plants can add bold splashes of color indoors. Cultivars selected to remain brightly colored under indoor conditions are grown for interiorscaping. Some of these improved varieties can maintain quality for months under interior light levels as low as 100 foot-candles; however, most will benefit from higher light levels.

\section{General Cultural Requirements}

\section{Temperature:}

\section{USDA HARDINESS ZONES: 9b-11}

C. variegatum is a tropical plant that can be cold damaged by temperatures below about $50^{\circ} \mathrm{F}$ $\left[10^{\circ} \mathrm{C}\right]$.

Soil: Plants grown in ground beds can be grown satisfactorily in native soils from sand to peats as long as they are well drained. High $\mathrm{pH}$ rock soils should be avoided because of induced micronutrient deficiencies. Plants grown in containers can be maintained for several years in a medium composed of peat moss:pine bark:sand (6:3:1 ratio) or peat moss:sand (3:1 ratio).

Fertilization: Crotons grown in ground beds require less fertilizer per unit of surface area than plants grown in pots. Soil $\mathrm{pH}$ should be in the range 
of 4.5 to 6.5. Adjust soil $\mathrm{pH}$ with dolomite or sulfur. Fertilizers with a ratio near 3-1-2 $\left(\mathrm{N}-\mathrm{P}_{2} \mathrm{O}_{5}-\mathrm{K}_{2} \mathrm{O}\right)$ produce excellent plants, and either liquid or slow release forms may be utilized. Pot-grown plants require 1,500-2,000 pounds $(\mathrm{lb})$ nitrogen $(\mathrm{N}) /$ acre (A)/year (yr) [1,680-2,240 kilograms (kg) N/hectare (ha)/yr] from a 3-1-2 ratio fertilizer while $900 \mathrm{lb}$ $\mathrm{N} / \mathrm{A} / \mathrm{yr}[1,000 \mathrm{~kg} \mathrm{~N} / \mathrm{ha} / \mathrm{yr}]$ is adequate for bed-grown plants. Excess fertilizer will reduce intensity of foliar coloration, reduce root system size and possibly lead to nutrient runoff into surface waters and/or leaching downward into ground waters.

Light: The color of croton leaves is strongly influenced by light intensity; therefore, it is important to grow plants under proper shade levels. Landscape varieties grow well in full sun. However, excessive light can cause fading of colors like red and orange. Conversely, excessive shade will prevent proper color development. Light level also affects leaf size, with high light reducing leaf size and heavy shade resulting in larger leaves. New leaves of crotons appear green and change to normal coloration with time under proper light. Plants also develop normal leaf coloration faster during cooler seasons than during the summer when they are growing rapidly. Suggested shade percentages for stem production in Florida are 30 to $47 \%$. For most cultivars, $30 \%$ shade is not quite enough in summer, but $47 \%$ is too much in winter. For plants intended for use in interiorscapes, production shade levels of 50 to $70 \%$ are recommended $(3,000-5,000 \mathrm{ft}-\mathrm{c})$.

Water: Crotons have one of the highest transpiration rates of commonly grown foliage plants and require frequent irrigations. Slight wilting of young foliage does not slow growth rate and thus should be used as a guide to watering. One inch of water per week will usually be adequate for bed-grown plants, while daily applications may be necessary for container-grown plants during certain times of the year.

Planting: For leaf and stem production, crotons are planted directly in ground beds from 6 inches [15 centimeters $(\mathrm{cm})]$ or larger pots and spaced 3 to 4 feet [0.9 to 1.2 meter $(\mathrm{m})$ ] on center in rows 6 to 8 feet [1.8 to $2.4 \mathrm{~m}$ ] apart depending on shadehouse post spacing. Container plants should be grown in 4 to 7 gallon sizes and spaced 3 to 4 feet on center in rows 5 to 7 feet [1.5 to $2.1 \mathrm{~m}$ ] apart. Spacing depends to a large extent on the rate of leaf and/or stem removal for sales, and thus is affected by grower practices. In the landscape, plant spacing of 2 to 3 feet $[0.6$ to $0.9 \mathrm{~m}$ ] is suggested.

Propagation: Crotons are usually propagated under mist from tip cuttings 3 to 6 inches [ 8 to $15 \mathrm{~cm}$ ] long having 3 to 5 leaves. Cuttings root within four weeks provided temperature of the propagation medium is between $70^{\circ}$ and $80^{\circ} \mathrm{F}\left[21^{\circ}\right.$ and $27^{\circ} \mathrm{C}$ ]. Rooting time is lengthened by several weeks if the medium temperature is below $70^{\circ} \mathrm{F}$ but above $60^{\circ} \mathrm{F}\left[16^{\circ} \mathrm{C}\right]$. Open, well aerated propagation media such as a 1:1 (by volume) combination of perlite and Sphagnum peat moss is suggested. Be aware that croton leaves will produce roots at the petiole base but do not grow on to produce new plants. This phenomenon is commonly observed in flower arrangements that have had only water added as a holding solution (Figure 3) and can lead to leaves with exceptionally long vase lives.

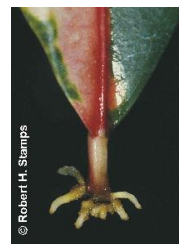

Figure 5. Croton leaves will produce roots at the base of the petiole if held in water; however, new plants are propagated using stem cuttings.

\section{Common Cultural Problems}

Pests: Crotons are fairly pest-free; however, insects, mites and pathogens should be scouted for and controlled as needed.

\section{Insects}

1) Mealybugs (citrus mealybug, Planococcus citri; long tailed mealybug, Pseudococcus longispinus; striped mealybug, Ferrisia virgata; pink hibiscus mealybug, Maconelliconccus hirsutus)

Symptoms - Mealybugs appear as white cottony masses on roots, lower leaf surfaces and in leaf axils. 
Sticky honeydew and black sooty mold may be present.

\section{Control - Systemic materials are preferred} because it is difficult to penetrate the waxy outer coating of mealybugs. Insecticides that coat and suffocate all developmental stages (e.g., oils) also can be effective. See http://edis.ifas.ufl.edu/IG012 for a listing of products available for mealybug control. Prior to widespread use, test new products for crop safety by making multiple applications to a small block of representative plants and checking for damage.

2) Scales (numerous species - black, chaff, Florida wax, glover, green shield, hemispherical, lesser snow, purple, etc.)

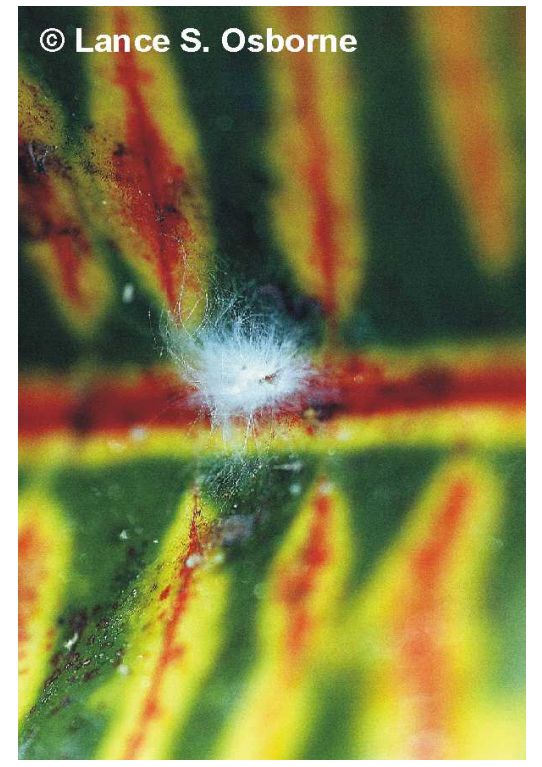

Figure 6. Philephedra tuberculosa scale on a croton leaf.

Symptoms - Scales can feed on croton leaves, petioles and stems, and because of their variable shapes, sizes and colors, they may be hard to diagnose. Some crawlers produce honeydew.

Control - Control of scale is similar to that for mealy bugs (see above). See http://edis.ifas.ufl.edu/IG012 for a listing of products available for scale control. Prior to widespread use, test new products for crop safety by making multiple applications to a small block of representative plants and checking for damage.
3) Thrips (greenhouse thrip, Heliothrips haemorrhoidalis; others)

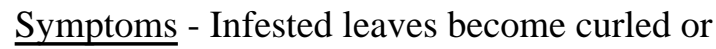
distorted when attacked during their early development. Other symptoms include silver gray scars or calloused areas where feeding has occurred. Larvae carry around a large drop of excreta that may be deposited on the leaf leaving a small dark dot.

Control - See http://edis.ifas.ufl.edu/IG012 for a listing of products available for controlling thrips. Prior to widespread use, test new products for crop safety by making multiple applications to a small block of representative plants and checking for damage.

\section{Mites}

\section{1) Spider mites (Tetranychus spp.)}

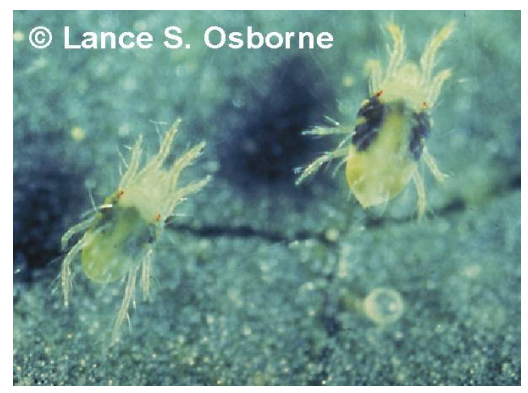

Figure 7. The two-spotted spider mite (Tetranychus urticae) is the major arthropod pest of crotons.

Symptoms - These mites are very small and typically are found on the undersides of leaves. When present, they can be detected by beating leaves against a light-colored surface and looking for these eight-legged creatures running across the surface. Unless actively scouted for, two-spotted spider mites are often not detected until plants are severely infested. Mite feeding causes foliage to become speckled and may induce yellowing.

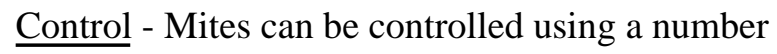
of miticides. The critical factor in any control program is thorough coverage of the foliage (especially the lower surface) with the miticide. See http://edis.ifas.ufl.edu/IG012 for a listing of products available for controlling mites. Prior to widespread use, test new products for crop safety by making multiple applications to a small block of representative plants and checking for damage. 


\section{2) Broad mites (Polyphagotarsonemus latus)}

Symptoms - These mites are almost microscopic and therefore hard to detect. Their feeding causes foliage to become distorted. Leaves may curl downward and turn color (orangey to purplish). Internodes may become shortened and broad mite feeding may increase lateral bud break. Damage can include generally unthrifty growth and stunting.

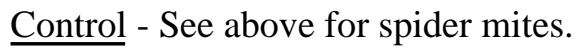

Table 1 lists known insecticide and miticide safety and phytotoxicity on crotons.

Main diseases: Crotons are fairly disease-free but are susceptible to some bacterial and fungal diseases. Since the fungal diseases are fairly uncommon, none will be covered in this publication.

\section{Bacterial}

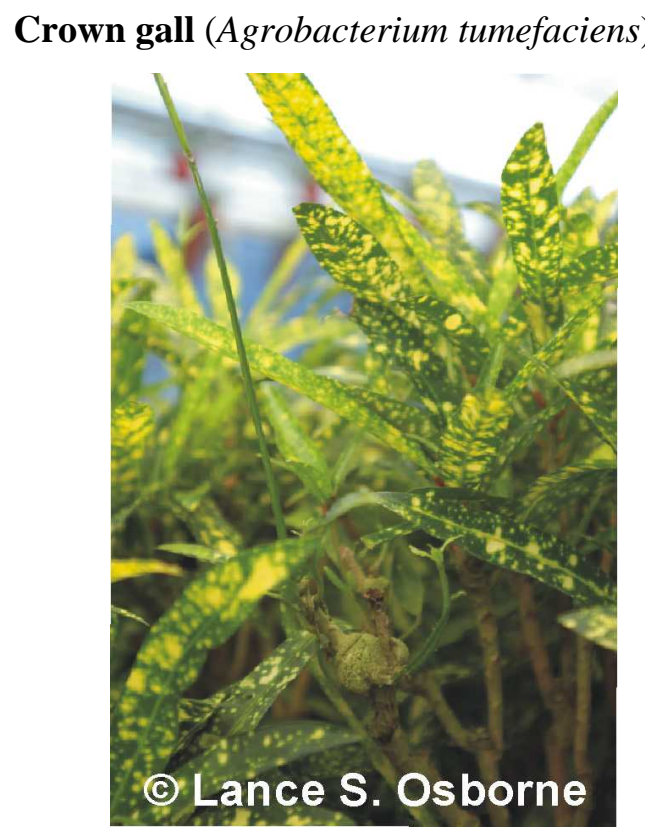

Figure 8. Crown gall of croton caused by the bacterium Agrobacterium tumefaciens.

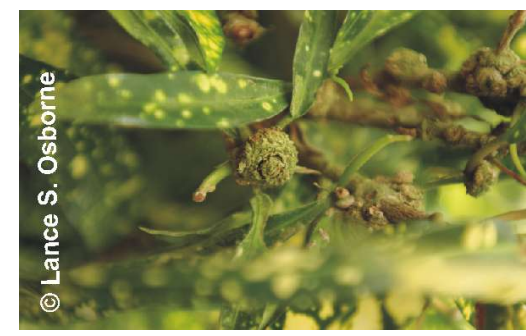

Figure 9. Agrobacterium tumefaciens gall on croton.
Symptoms - Swollen, eventually corky, areas on stems and leaf veins. Can even cause swollen roots. Common where cuttings have been taken. Other pathogens can cause galling so an accurate disease diagnosis should be made to determine if $A$. tumefaciens is the cause of the problem.

Control - Destroy all plants found infected with this bacterium. Sterilize any cutting tools between plants when pruning or taking cuttings.

\section{Harvesting and Postharvest Considerations}

Harvesting and Handling: For use by florists, croton leaves are harvested by twisting the leaves off the stem so they detach at the base of the petiole. The leaves are frequently bundled ten per bunch and secured with a rubber band. Stems of croton leaves are harvested using clippers. Postharvest fungicide treatments (dips) are helpful in controlling diseases during storage [check fungicide labels for registration for this use].

Storage and Shipping: The recommended storage temperature range for crotons is $35-40^{\circ} \mathrm{F}$ $\left[2-4^{\circ} \mathrm{C}\right]$ : however, research indicates that crotons can be successfully stored for two weeks at temperatures up to $60^{\circ} \mathrm{F}\left[16^{\circ} \mathrm{C}\right]$. Research indicates that the use of floral preservatives may be detrimental to the longevity of croton leaves.

Problems: Desiccation is the predominant postharvest problem encountered when using croton leaves. The use of antitranspirant materials, such as clear plastic sprays, has been suggested.

\section{Selected References}

Benz, M.B. and J.L. Johnson. 1986. Flowers: Geometric Form. San Jacinto Publishing Co.

Conover, C.A. and R.T. Poole. 1983. Influence of shade and fertilizer levels on yield of croton stock plants. Proc. Fla. State Hort. Soc. 96:261-263.

Conover, C.A. and R.T. Poole. 1990. Light and fertilizer recommendations for production of acclimatized potted foliage plants. Univ. of Fla. IFAS, Central Fla. Res. and Ed. Cntr. - Apopka, CFREC-Apopka Res. Rpt. RH-90-1. 
Dehgan, B. 1998. Landscape Plants for Subtropical Climates. Univ. Presses of Florida, Gainesville, FL.

Gilman, E.F. 1996. Florida Plant Guide. Betrock Information Systems, Hollywood, FL.

Hardenburg, R.E., A.E. Watada, and C.Y. Wang. 1986. The Commercial Storage of Fruits, Vegetables, and Florist and Nursery Stocks. U.S.D.A., Agr. Res. Serv., Agr. Handbook No. 66.

Henny, R.J., L.S. Osborne and A.R. Chase. 1991. Croton. Univ. of Fla. IFAS, Central Fla. Res. and Ed. Cntr.-Apopka Foliage Plant Res. Note RH-91-12.

Hunter, N.T. 1994. The Art of Floral Design. Delmar Publishers, Albany, NY.

McConnell, D.B., R.W. Henley, and R.L. Biamonte. 1981. Commercial foliage plants, pp. 544-593. In: J.N. Joiner (ed.). Foliage Plant Production. Prentice-Hall, Englewood Cliffs, NJ.

Poole, R.T. and C.A. Conover. 1987. Heat stress of foliage plants. Univ. of Fla.. IFAS, Central Fla. Res. and Ed. Cntr.-Apopka, CFREC-Apopka Res. Rpt. RH-87-2.

Poole, R.T. and C.A. Conover. 1990. Effects of light intensity and fertilizer formulation on six foliage plants growing indoors. Univ. of Fla.. IFAS, Central Fla. Res. and Ed. Cntr.-Apopka, CFREC-Apopka Res. Rpt. RH-90-16.

Reeves, R.G. and A. Bell. 1988. Codiaeum variegation pictum - A foliage favorite with new possibilities. Fla. Nurseryman 35(1):69, 71, 75, 78.

Short, D.E., L.S. Osborne, and R.W. Henley. 1984. Phytotoxicity of insecticides and miticides to foliage and woody ornamental plants. Univ. of Fla., IFAS., Exten. Entomology Rpt. \#57.

Stamps. R.H. 1985. Effects of production shade level, foliage maturity, antitranspirants, floral preservative and cultivar on vase life of woody cut foliage crops. Proc. Fla. State Hort. Soc. 98:99-100.
Stamps. R.H. 1987. Major Florida cut foliage crops classified according to floral design and landscape usage. Proc. Fla. State Hort. Soc. 100:179-180. 
Table 1.

\begin{tabular}{|c|c|c|c|}
\hline \multicolumn{4}{|c|}{ Phytotoxicity of Insecticides and Miticides on Crotons (published and unpublished data) } \\
\hline Safe & Unsafe & Questionable & Unknown \\
\hline Avid & Malathion EC & Akari & Adept \\
\hline Bacillus thuringiensis & Malathion EC + oil & & Azatin XL \\
\hline Di-Syston EC & Morestan WP & & Conserve SC \\
\hline Dursban & & & Decathalon 20WP \\
\hline Enstar II & & & Deltaguard \\
\hline Floramite & & & Distance \\
\hline Hexygon & & & Endeavor \\
\hline Kelthane EC & & & Malathion $57 \%$ EC \\
\hline Marathon II, 60WP, $1 \% \mathrm{G}$ & & & Mesurol 75W \\
\hline Mavrik & & & Ovation SC \\
\hline M-Pede & & & Thiodan \\
\hline \multicolumn{4}{|l|}{ Orthene 97} \\
\hline \multicolumn{4}{|l|}{ Pylon } \\
\hline \multicolumn{4}{|l|}{ Sanmite } \\
\hline \multicolumn{4}{|l|}{ Sevin WP } \\
\hline \multicolumn{4}{|l|}{ Talstar } \\
\hline \multicolumn{4}{|l|}{ Triact 70} \\
\hline \multicolumn{4}{|l|}{ Vendex 50WP } \\
\hline
\end{tabular}

